\title{
Implications of the clinical gestational diagnosis of ZIKV infection in the manifestation of symptoms of postpartum depression: a case-control study
}

Eleomar Vilela Moraes ${ }^{1,5^{*}}$ (D), Olegário Rosa Toledo², Flávia Lúcia David², Bruna Nascimento Godoi³ Keila Araujo Monteiro ${ }^{3}$, Thaisa Cimardi Deluqui ${ }^{3}$, Thais Wérica Teixeira ${ }^{3}$, Andiara Luiza Carvalho ${ }^{3}$ and Mariza Martins Avelino ${ }^{4}$

\begin{abstract}
Background: Traumatic events can trigger postpartum depression. Pregnant women in Brazil today are facing an extremely stressful experience. Thus, the objective here was to analyze the prevalence of symptoms of depression in the immediate postpartum period (IPPD) and associate these symptoms with previous stressful, social, psychological, behavioral, obstetrical, clinical, violent and infectious events, particularly exposure to Zika virus (ZIKV) infection during pregnancy.

Methods: This was a case-control study. The sample comprised 213 puerperal women treated in the maternity ward of a public reference hospital in the Araguaia River Valley of Mato Grosso and Goiás, Brazil. Severe IPPD symptoms were confirmed based on the Edinburgh Postnatal Depression Scale (EPDS). A descriptive statistical analysis was carried out using the Epi Info' ${ }^{\mathrm{TM}}$ version 7.1.5 suite of software tools and the Statistical Package for Social Sciences (SPSS) version 21.0.

Results: A bivariate analysis revealed a significant association between "severe symptoms of IPPD" and the following variables: "clinical diagnosis of ZIKV during pregnancy" ( $\mathrm{OR}=13.36$; $95 \% \mathrm{Cl}=5.34-33.39)$ ); "was separated or divorced in the last year" ( $\mathrm{OR}=3.58 ; 95 \% \mathrm{Cl}=1.42-8.99)$; "suffered an accident in the last year" ( $\mathrm{OR}=3.32,95 \% \mathrm{Cl}=1.12-9.82)$; "suffered emotional violence during pregnancy" ( $\mathrm{OR}=3.80 ; 95 \% \mathrm{Cl}=1.81-7.99) ;$ "suffered physical violence during pregnancy" ( $\mathrm{OR}=11.86 ; 95 \% \mathrm{Cl}=2.07-67.82)$; "fear of her partner" ( $\mathrm{OR}=17.90 ; 95 \% \mathrm{Cl}=3.44-92.99)$; "dengue fever during pregnancy" (OR $=7.85 ; 95 \% \mathrm{Cl}: 1.66-37.05)$, and "has a family member diagnosed with mental illness" $(\mathrm{OR}=2.54 ; 95 \% \mathrm{Cl}=$ 1.09-5.93). The multivariate analysis confirmed the association of severe PPD symptoms only with the variables of "clinical diagnosis of ZIKV during pregnancy" (OR=19.82; 95\% Cl: 5.35-73.39) and "was separated or divorced in the last year" $(\mathrm{OR}=3.92 ; 95 \% \mathrm{IC}=1.12-13.63)$.
\end{abstract}

Conclusions: Clinically diagnosed ZIKV during pregnancy may be one of the main events associated with severe IPPD symptoms, showing an almost 20-fold higher chance of occurrence than other factors.

Keywords: Pregnancy, Puerperium, Women, Divorce, EPDS

\footnotetext{
* Correspondence: veleomar@gmail.com

${ }^{1}$ School of Medicine, Federal University of Goiás- UFG, Av. Primeira Avenida,

s/n, Setor Leste Universitário, Goiânia, GO 74605-020, Brazil

${ }^{5}$ Avenida Getúlio Vargas, 663, Aragarças, GO 76240-000, Brazil

Full list of author information is available at the end of the article
}

(c) The Author(s). 2019 Open Access This article is distributed under the terms of the Creative Commons Attribution 4.0 International License (http://creativecommons.org/licenses/by/4.0/), which permits unrestricted use, distribution, and reproduction in any medium, provided you give appropriate credit to the original author(s) and the source, provide a link to the Creative Commons license, and indicate if changes were made. The Creative Commons Public Domain Dedication waiver (http://creativecommons.org/publicdomain/zero/1.0/) applies to the data made available in this article, unless otherwise stated. 


\section{Introduction}

The World Health Organization (WHO, 2012) [1] states that unipolar depressive disorders will be the leading cause of women's illness worldwide by 2030. Postpartum depression (PPD) is a non-communicable depressive disorder that can occur up to 1 year postpartum [2]. The prevalence of PPD is approximately 19.8\% in developing countries [3] and $26.3 \%$ in Brazil [4]. Albeit treatable, PPD causes widespread suffering among mothers and their babies, with negative effects on the entire family. The basic symptoms of PPD are sadness, anxiety, low self-esteem, decreased concentration and social contact, and they may coexist with different somatic disorders and even panic attacks [5].

A recent study involving 23,894 Brazilian puerperal women confirmed several risk factors for postpartum depression, such as low income, history of mental disorder, unplanned pregnancy and multiparity [4]. The literature also describes other predictive factors, such as marital conflicts, anxiety [6, 7], genetic factors, exposure to violence [1], history of emotional problems [8], diseases during pregnancy [3] and traumatic and/or stressful events [3, 7, 9].

Pregnant women in Brazil today are facing an extremely stressful experience that is a grave concern for the world population. The country is experiencing an outbreak of Zíka virus (ZIKV) transmitted by the mosquito Aedes (A. aegypti and A. albopictus). Based on several studies, the $C D C$ confirmed that pregnant women can transmit ZIKV to their fetus throughout gestation, with the risk of causing microcephaly and other brain defects [10]. According to Brazil's Ministry of Health (MS), 13,719 suspected cases have been diagnosed since the beginning of the outbreak [11].

In this context, several studies have shown that traumatic events can trigger PPD $[7,9]$, predisposing those who suffer from this disorder to adopt a less healthy lifestyle, with a history of risky attitudes $[12,13]$ that lead to poor health [14]. Therefore it can be stated that pregnant women in Brazil, who are potentially vulnerable to ZIKV, have become emotionally affected.

Thus, the objective here was to analyze the exposure to clinically diagnosed ZIKV infection during pregnancy and its association with symptoms of IPPD.

\section{Methods}

An unpaired case-control study was carried out from April 2016 to August 2017 to evaluate exposure to clinically diagnosed ZIKV infection during pregnancy in puerperal patients ready to be discharged from hospital. These women were patients in the maternity ward of a public reference hospital in Barra do Garças, state of Mato Grosso (MT), which serves the Araguaia River Valley of Mato Grosso and Goiás, Brazil.
The sample was probabilistic and involved puerperal women 18 years or older. Women displaying symptoms of depression (EPDS $\geq 13$ ) in the immediate postpartum period (2nd or 3rd day postpartum), exposed or not to ZIKV, were considered "cases," while puerperal women without symptoms of depression (EPDS < 13), exposed or not to ZIKV, were considered "controls."

The sample size was calculated using OpenEpi version 3.01 software [15]. A frequency of exposure of $67 \%$ was predicted among the cases [16], and of $40 \%$ among the controls, with a detection power (1- $\beta$ ) of $80 \%$, confidence level of $95 \%$, and a case-to-control ratio of one to five. The minimum number obtained was 40 cases and 119 controls, with a sample size of 159 puerperal women [17]. Given the possibility of losses, this number was increased by $34 \%$, making a total of 213 respondents.

Data were collected on alternate days, when half of the puerperal women were invited to participate. It was decided to divide the study into segments for easier understanding. An investigation was made into the probable relationship between PPD symptoms and several variables known to be correlated with this disorder (social, economic, cultural, demographic, psychological, behavioral, stressful and obstetric characteristics, history of violence, and clinical and infectious diseases).

The first segment consisted of screening depression symptoms based on the Edinburgh Postnatal Depression Scale (EPDS), whose questions are structured, closed and standardized for epidemiological studies. The EPDS was originally developed by Cox and Holden [18], and the Portuguese version of the scale, which was devised by Santos et al. [19], consists of 10 questions, each containing four score options, from 0 to 3 , with a maximum score of 30. The cut-off point used for the diagnosis of symptoms of depression was $\geq 13$, which is specific for a high-risk population and ensures $59.5 \%$ sensitivity and 88.4\% specificity [19].

Cases of violence against pregnant women were also screened using the Abuse Assessment Screen (AAS). This tool was developed in the USA [20] and has been validated in Brazil [21]. The abridged version of the tool has five closed and open questions that identify the persistence and seriousness of the physical abuse, the parts of the body injured on a specific occasion, and the profile of the aggressor. The AAS has proved to be a suitable tool for the detection of violence against pregnant women [22, 23].

The second segment consisted of investigating several stressful events experienced by puerperal women, such as behavior, obstetric complications during the current pregnancy, and previous psychiatric history of the pregnant woman and her family.

The third segment involved the social, economic, cultural and demographic characteristics, assessing the location of residence, level of education, marital 
status, occupation and socioeconomic status. A low level of education was defined as less than or up to 8 years of schooling, and the socioeconomic status was determined based on the criteria proposed by the Brazilian Market Research Association (ABEP) [24]. The last two segments of the questionnaire were developed by the research team, which used bold font for explanatory notes to facilitate filling out, applying and typing. This part of the questionnaire was validated in a pilot study.

The pilot study was previously applied to 15 puerperal women in order to detect not only possible errors in the investigation but also ambiguities and difficulties in understanding the questions composed by the authors of this study. After identifying all possible errors, the necessary corrections were made.

The reliability of the EPDS scale was checked by calculating Cronbach's alpha, according to which, the higher the coefficient the more reliable the instrument [25]. Thus, a coefficient above 0.70 was adopted as suitable for this study [26].

Excluded from this study were illiterate puerperal women getting treated for depression, women who failed to answer all the EPDS questions, and women with a previously diagnosed neurological disorder.

The data were evaluated using SPSS version 20 software (Statistical Package for Social Sciences). The variables were analyzed statistically using measures of central tendency (mean and median), dispersion (standard deviation) and frequency. Associations were verified based on a bivariate analysis using the $\chi^{2}$ test, Mantel-Haenszel test, Fisher's Exact test and the Odds Ratio (OR), while logistic regression was used for the multivariate analysis. The input data were of the hierarchical type and the explanatory variables were based on the borderline $p$-value $(p \leq 0.10)$ and on clinical importance [27]. A linear regression analysis was performed to identify possible multicollinearity between the independent variables $[28,29]$. In all the tests, a p-value lower than or equal to $5 \%$ ( $p \leq$ $0.05)$ was considered to be of statistical significance within a $95 \%$ confidence interval. The main independent variable was a "clinically diagnosed ZIKV infection during pregnancy." This diagnosis was confirmed based on the notification report issued by the Department of Health of the city of Barra do Garças, MT. "IPPD symptoms" was defined as a dependent variable.

This study was approved by the Research Ethics Committee (CEP) of the Federal University of Mato Grosso (UFMT) under Protocol CEP/UFMT/2015 No. 975.413, in line with Resolution No. 466/12 of the National Health Council of the Brazilian Ministry of Health.

\section{Results}

Among the puerperal women with IPPD, $11.27 \%$ exhibited mild or moderate symptoms of depression (10 to 12 points) and $16.90 \%$ displayed severe symptoms (13+ points). As for the internal consistency of the total dataset, Cronbach's alpha for the EPDS was 0.82, indicating the high reliability of the measurements (Table 1).

The interviewees ranged in age from 18 to $45(25 \pm$ 5.51). Most of them had more than 8 years of schooling (75.12\%), a husband or partner (75.59\%), a monthly income of more than three minimum salaries (47.00\%), were self-employed $(69.00 \%)$, and had a formally employed partner $(50.70 \%)$. Furthermore, a significant number of them identified themselves racially as black (73.24) and lived in the outskirts, i.e., the poorest neighborhoods, of urban areas (86.85\%). It was also found that $51.64 \%$ of them had not traveled during their pregnancy. The bivariate analysis revealed no statistically significant association between the variables.

Upon analyzing the history of stressful events, a significant association was found between a patient's IPPD symptoms and her separation or divorce in the last year $(\mathrm{OR}=3.58)$, a clinical diagnosis of ZIKV infection during pregnancy $(\mathrm{OR}=13.36)$, and an accident in the last year $(\mathrm{OR}=3.32)$. Surprisingly, however, this disorder was not influenced by any behavioral aspect (Table 2).

An analysis of the history of violence (Table 3) revealed a significant association between PPD symptoms and the variables of "emotional violence during pregnancy" $(\mathrm{OR}=3.80)$; "physical violence during pregnancy" $(\mathrm{OR}=11.86)$ and "fear of her partner" $(\mathrm{OR}=17.90)$.

As can be seen in Table 4, an association was found between PPD symptoms and puerperal women who had a family member with a diagnosis of mental disorder $(\mathrm{OR}=2.54)$ and dengue fever during pregnancy $(\mathrm{OR}=7.85)$.

Lastly, Table 5 describes a multivariate analysis of the variables, unlike the preceding tables, which

Table 1 Description of IPPD symptoms, Brazil, $2017(n=213)$

\begin{tabular}{llllll}
\hline EPDS $^{\mathrm{a}}$ (10 items) & $\mathrm{n}(\%)$ & $\begin{array}{l}\text { Cronbach's } \\
\text { Alpha }\end{array}$ & Interval & Median & $\begin{array}{l}\text { Mean } \\
\text { (SD) }\end{array}$ \\
\hline & & 0.82 & $0-27$ & 6 & $\begin{array}{l}7.06 \\
(5.54)\end{array}$ \\
No IPPD (0-9 points) & 153 & 71.83 & & & \\
$\begin{array}{l}\text { Mild/Moderate IPPD } \\
\text { (10-12 points) }\end{array}$ & 24 & 11.27 & & \\
Severe IPPD (13+ points) & 36 & 16.90 & & \\
\hline
\end{tabular}

SD Standard deviation; ${ }^{\text {a }}$ Score of $\geq 13$ on the EPDS Edinburgh postnatal depression scale 
Table 2 Behavioral characteristics and stressful events pertaining to the health of puerperal women, Brazil, 2017 $(n=213)$

\begin{tabular}{|c|c|c|c|c|}
\hline \multirow[t]{3}{*}{ Characteristics } & \multicolumn{2}{|c|}{ PPD Symptoms ${ }^{a}$} & \multicolumn{2}{|l|}{ Statistics } \\
\hline & Cases & Controls & OR (Cl 95\%) & $p^{*}$ \\
\hline & $\mathrm{n} \quad \%$ & $\%$ & & \\
\hline
\end{tabular}

Behavioral variable ${ }^{b}$

Consumption of alcohol beverages during pregnancy

$\begin{array}{lllllll}\text { Yes } & 6 & 18.18 & 27 & 81.82 & 1.14(0.43-3.01) & 0.989^{*} \\ \text { No } & 29 & 16.29 & 149 & 83.71 & & \end{array}$

Cigarette smoker

$\begin{array}{lllllll}\text { Yes } & 9 & 20.00 & 36 & 80.00 & 1.38(0.59-3.21) & 0.603^{*}\end{array}$

$\begin{array}{lllll}\text { No } & 25 & 15.34 & 138 & 84.66\end{array}$

User of marijuana, cocaine, freebase or crack before pregnancy

$\begin{array}{lllllll}\text { Yes } & 3 & 27.27 & 8 & 72.73 & 1.97(0.50-7.82) & 0.397^{* *} \\ \text { No } & 32 & 16.00 & 168 & 84.00 & & \end{array}$

Was in contact with chemicals (pesticides) during pregnancy

$\begin{array}{lllllll}\text { Yes } & 7 & 25.00 & 21 & 75.00 & 1.78(0.69-4.57) & 0.347^{*} \\ \text { No } & 29 & 15.76 & 155 & 84.24 & & \end{array}$

History of stressful events ${ }^{\mathrm{b}}$

Clinical diagnosis of ZIKV during pregnancy

$\begin{array}{lllllll}\text { Yes } & 16 & 61.54 & 10 & 38.46 & 13.36(5.34-33.39) & 0.001^{*} \\ \text { No } & 20 & 10.70 & 167 & 89.30 & & \end{array}$

Separated or divorced in the last year

$\begin{array}{lllllll}\text { Yes } & 9 & 37.50 & 15 & 62.60 & 3.58(1.42-8.99) & 0.011^{*}\end{array}$

$\begin{array}{lllll}\text { No } & 27 & 14.36 & 161 & 85.64\end{array}$

Lost her job in the last year

$\begin{array}{lllllll}\text { Yes } & 5 & 18.52 & 22 & 81.48 & 1.13(0.40-3.21) & 0.787^{* *} \\ \text { No } & 31 & 16.76 & 154 & 83.24 & & \end{array}$

Was involved in a lawsuit in the last year

$\begin{array}{lllllll}\text { Yes } & 6 & 31.58 & 13 & 68.42 & 2.51(0.88-7.11) & 0.103^{* *}\end{array}$

$\begin{array}{lllll}\text { No } & 30 & 15.54 & 163 & 84.46\end{array}$

Someone close to her died in the last year

$\begin{array}{lllllll}\text { Yes } & 10 & 17.54 & 47 & 82.46 & 1.10(0.49-2.46) & 0.985^{*} \\ \text { No } & 25 & 16.23 & 129 & 83.77 & & \end{array}$

Was assaulted in the last year

$\begin{array}{lllllll}\text { Yes } & 0 & 0.00 & 1 & 100.00 & 1.20(1.130-1.275) & 1.000^{* *} \\ \text { No } & 35 & 16.67 & 175 & 83.33 & & \end{array}$

A thief broke into her home in the last year

$\begin{array}{lllllll}\text { Yes } & 0 & 0.00 & 9 & 100 & 1.21(1.136-1.288) & 0.361^{* *} \\ \text { No } & 35 & 17.33 & 167 & 82.67 & & \end{array}$

Suffered an accident in the last year

$\begin{array}{lllllll}\text { Yes } & 6 & 37.50 & 10 & 62.50 & 3.32(1.12-9.82) & 0.035^{* *} \\ \text { No } & 30 & 15.31 & 166 & 84.69 & & \end{array}$

OR Odds ratio, $\mathrm{Cl}$ Confidence interval; $\times 2$ Test; *Mantel-Haenszel test; $* *$ Fisher's Exact test; ${ }^{\text {a }}$ core of $\geq 13$ on the EPDS Edinburgh postnatal depression scale;

${ }^{\mathrm{b}}$ Some did not respond
Table 3 Evaluation of severe symptoms of IPPD attributed to violence suffered during pregnancy, Brazil, $2017(n=213)$

\begin{tabular}{|c|c|c|c|c|c|c|}
\hline \multirow[t]{3}{*}{ Characteristics } & \multicolumn{4}{|c|}{ PPD Symptoms ${ }^{a}$} & \multicolumn{2}{|l|}{ Statistics } \\
\hline & \multicolumn{2}{|c|}{ Cases } & \multicolumn{2}{|c|}{ Controls } & \multirow[t]{2}{*}{$\overline{O R}(\mathrm{Cl} 95 \%)$} & \multirow[t]{2}{*}{$p$} \\
\hline & $\mathrm{n}$ & $\%$ & $\mathrm{n}$ & $\%$ & & \\
\hline \multicolumn{7}{|c|}{ History of violence ${ }^{b}$} \\
\hline \multicolumn{7}{|c|}{ Emotional violence during pregnancy } \\
\hline Yes & 19 & 32.20 & 40 & 67.80 & $3.80(1.81-7.99)$ & $0.001^{*}$ \\
\hline No & 17 & 11.11 & 136 & 88.89 & & \\
\hline \multicolumn{7}{|c|}{ Physical violence during pregnancy } \\
\hline Yes & 4 & 66.67 & 2 & 33.33 & $11.86(2.07-67.82)$ & $0.007^{* *}$ \\
\hline No & 28 & 14.48 & 166 & 85.57 & & \\
\hline \multicolumn{7}{|c|}{ Sexual abuse in the last year } \\
\hline Yes & 1 & 50.00 & 1 & 50.00 & $5.21(0.32-85.43)$ & $0.302^{* *}$ \\
\hline No & 33 & 16.10 & 172 & 83.90 & & \\
\hline \multicolumn{7}{|c|}{ Fear of her partner } \\
\hline Yes & 6 & 75.00 & 2 & 25.00 & 17.90(3.44-92.99) & $0.001^{* *}$ \\
\hline No & 29 & 14.36 & 173 & 85.64 & & \\
\hline \multicolumn{7}{|c|}{ Fear of someone else } \\
\hline Yes & 3 & 33.33 & 6 & 66.67 & $2.68(0.64-11.28)$ & $0.170^{* *}$ \\
\hline No & 31 & 15.74 & 166 & 84.26 & & \\
\hline
\end{tabular}

OR Odds ratio, $\mathrm{Cl}$ Confidence interval; $\mathrm{X} 2$ test; ${ }^{*}$ Mantel-Haenszel test; $; *$ Fisher's Exact test; ${ }^{a}$ Score of $\geq 13$ on the EPDS Edinburgh postnatal depression scale;

${ }^{\mathrm{b}}$ Some did not answer

describe the bivariate analysis. Among all the evaluated characteristics, only puerperal women with a "clinical diagnosis of ZIKV infection during pregnancy" (OR $=19.82)$ and women divorced or separated from their partner in the last year $(O R=3.92)$ showed a confirmed association with the symptoms of IPPD. Multicollinearity between the independent variables was found to be weak, since the Variance Inflation Factor (VIF) varied from 1.12 to 1.14 [29].

\section{Discussion}

This may be the first study that investigates the association between IPPD and the clinical diagnosis of ZIKV infection in Brazil. It should be noted that, after adjusting the confounding variables, the episodes of "separation or divorce in the last year" $(\mathrm{OR}=3.72)$ and "clinical diagnosis of ZIKV infection during pregnancy" were associated with the onset of IPPD symptoms (OR = 19, 82).

It should be kept in mind that women treated at private hospitals and women treated for psychiatric disorders, among which mood disorders were common, were excluded from the study. Therefore, it is quite possible that IPPD symptoms are underestimated or underreported. On the other hand, results similar to those of this survey were reported in a Brazilian article, which used the same scale and cutoff point [30]. 
Table 4 Evaluation of clinical and obstetric history of severe symptoms of IPPD, Brazil, $2017(n=213)$

\begin{tabular}{|c|c|c|c|c|c|c|}
\hline \multirow[t]{3}{*}{ Characteristics } & \multicolumn{4}{|c|}{ PPD Symptoms ${ }^{b}$} & \multicolumn{2}{|l|}{ Statistics } \\
\hline & \multicolumn{2}{|c|}{ Cases } & \multicolumn{2}{|c|}{ Controls } & \multirow[t]{2}{*}{ OR (Cl 95\%) } & \multirow[t]{2}{*}{$p^{*}$} \\
\hline & $\mathrm{n}$ & $\%$ & $\mathrm{n}$ & $\%$ & & \\
\hline \multicolumn{7}{|l|}{ Clinical history $^{a}$} \\
\hline \multicolumn{7}{|c|}{ Dengue fever during pregnancy } \\
\hline Yes & 4 & 57.14 & 3 & 42.86 & $7.85(1.66-37.05)$ & $0.014^{* *}$ \\
\hline No & 27 & 14.52 & 159 & 85.48 & & \\
\hline \multicolumn{7}{|l|}{ Diagnosis of a STD } \\
\hline Yes & 3 & 30.00 & 7 & 70.00 & $2.19(0.54-8.93)$ & $0.379^{* *}$ \\
\hline No & 33 & 16.34 & 169 & 83.66 & & \\
\hline \multicolumn{7}{|c|}{ Family member diagnosed with a mental disorder } \\
\hline Yes & 12 & 25.53 & 35 & 74.47 & $2.54(1.09-5.93)$ & $0.050^{*}$ \\
\hline No & 15 & 11.90 & 111 & 88.10 & & \\
\hline \multicolumn{7}{|l|}{ Obstetric variables ${ }^{a}$} \\
\hline Multiparous & 27 & 20.45 & 105 & 79.55 & $2.31(1.00-5.38)$ & $0.073^{*}$ \\
\hline Primiparous & 8 & 10.00 & 72 & 90.00 & & \\
\hline \multicolumn{7}{|c|}{ Current pregnancy was planned } \\
\hline Yes & 21 & 16.03 & 110 & 83.97 & $0.90(0.40-2.01)$ & $0.964^{*}$ \\
\hline No & 11 & 17.46 & 52 & 82.54 & & \\
\hline \multicolumn{7}{|l|}{ Induced abortion } \\
\hline Yes & 2 & 66.67 & 1 & 33.33 & 10.42(0.92-118.31) & $0.123^{* *}$ \\
\hline No & 33 & 16.10 & 172 & 83.90 & & \\
\hline \multicolumn{7}{|c|}{ Spontaneous abortion } \\
\hline Yes & 8 & 17.178 & 37 & 82.22 & $1.09(0.46-2.60)$ & $0.974^{*}$ \\
\hline No & 27 & 16.56 & 136 & 83.44 & & \\
\hline \multicolumn{7}{|l|}{ Risky pregnancy } \\
\hline Yes & 11 & 21.57 & 40 & 78.43 & $1.60(0.72-3.57)$ & $0.347^{*}$ \\
\hline No & 23 & 14.65 & 134 & 85.35 & & \\
\hline \multicolumn{7}{|c|}{ Complications during pregnancy } \\
\hline Yes & 18 & 19.15 & 76 & 80.85 & $1.30(0.61-1.09)$ & $0.630^{*}$ \\
\hline No & 14 & 15.38 & 77 & 84.62 & & \\
\hline \multicolumn{7}{|l|}{ Prenatal care } \\
\hline No & 9 & 26.47 & 25 & 73.53 & $1.99(0.84-4.72)$ & $0.185^{*}$ \\
\hline Yes & 27 & 15.34 & 149 & 84.66 & & \\
\hline Cesarean section & 24 & 15.48 & 131 & 84.52 & $0.81(0.36-1.82)$ & $0.760^{*}$ \\
\hline Vaginal delivery & 10 & 18.52 & 44 & 81.48 & & \\
\hline
\end{tabular}

OR Odds ratio, $\mathrm{Cl}$ Confidence interval; $\times 2$ test; ${ }^{*}$ Mantel-Haenszel test; ${ }^{* *}$ Fisher's Exact test ${ }^{a}$ Some did not answer; ${ }^{\mathrm{b}} \mathrm{S} c o r e$ of $\geq 13$ on the EPDS Edinburgh postnatal depression scale

With regard to the instrument, the EPDS scale was adopted chosen due to its applicability, since it was validated in an equivalent population [19] and has been used in numerous studies on pregnancy and puerperium. A cut-off point of $\geq 13$ instead of $\geq 10$ was chosen in order to exclude false positives and eliminate patients with milder symptoms, thereby avoiding a conflicting diagnosis of "melancholia in motherhood" or "baby blues," which determines mild symptoms of depression immediately post delivery [19]. Moreover, this cutoff point is more favorable for diagnosing PPD symptoms in high-risk situations, preventing the loss of such women. It should be noted that the EPDS refers to the occurrence of PPD symptoms within a period of 7 days postpartum, and therefore does not exclude the possibility that this condition began during pregnancy [31-33]. 
Table $\mathbf{5}$ Logistic regression analysis of events associated with severe symptoms of IPPD, Brazil, $2017(n=213)$

\begin{tabular}{lll}
\hline Characteristics $^{\text {a }}$ & \multicolumn{2}{l}{ Statistics } \\
\cline { 2 - 3 } & OR (Cl 95\%) & $P$ \\
\hline Fear of her partner & 6.17 & 0.154 \\
& $(0.50-75.30)$ & \\
Clinical diagnosis of ZIKV infection during & 19.82 & 0.001 \\
pregnancy & $(5.35-73.39)$ & \\
Physical violence during pregnancy & 0.98 & 0.990 \\
& $(0.80-12.148)$ & \\
Dengue fever during pregnancy & 3.74 & 0.237 \\
& $(0.42-33.23)$ & \\
Emotional violence during pregnancy & 1.98 & 0.201 \\
& $(0.69-5.67)$ & \\
Separated or divorced in the last year & 3.92 & 0.032 \\
Had an accident in the last year & $(1.12-13.63)$ & \\
& 1.73 & 0.485 \\
& $(0.37-8.08)$ & \\
\hline
\end{tabular}

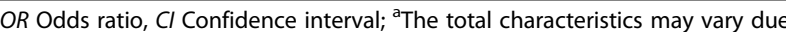
to lack of information; Score of $\geq 13$ in the EPDS Edinburgh postnatal depression scale

In this study, no correlation was found between social, demographic and economic status and PPD symptoms, possibly because most of the women were married, were on average 25 years old, had more than 8 years of schooling, and their husbands were formally employed. Thus, it is reasonable to infer that this population enjoyed a stable social and economic status. These data are corroborated by the findings of Abdollahi et al. [34], who reported a positive association between advanced maternal age, low educational level [8], low family income and risk of PPD [34]. Moreover, another study found a correlation between the marital status of single or separated and illness, and that married women were more protected [33].

As for possible risks to mother and baby health, stressful episodes should be carefully examined during prenatal consultations to ensure their early detection. Such episodes should be considered a normal topic of discussion, for even if many patients do not initially admit they are suffering, these consultations may provide opportunities to encourage them to seek help.

The findings of this survey highlight the importance of examining mental health in light of stressful events experienced during pregnancy and the postpartum period. In this context, the occurrence of marital separation or divorce in the last year showed a confirmed association with PPD in the multivariate analysis. After eliminating confounding events, the possibility of PPD symptoms occurring was almost four-fold higher. These findings are corroborated by those of Ward et al. [35], who monitored 10,231 pregnant women for 8 years and predicted a significant increase in the probability of PPD in cases of marital separation or divorce [35]. Thus, a dramatic change in the family, such as divorce during pregnancy, seems to have a negative impact on women's mental health. However, there is a paucity of literature on this subject, which underscores the need to include questions about stressors unique to divorce in research tools, thus facilitating the analysis of its potential consequences on the mother and unborn child.

Many questions about prenatal development remain unanswered, particularly about the consequences of stress and depression on the fetal environment. It is known that an increase in paternal PPD [36] may indicate that the hormonal feedback of the hypothalamicpituitary-gonadal (HPG) axis and hypothalamicpituitary-adrenal (HPA) axis are not the only components of these complex mechanisms [37], in which psychosocial [38] and genetic factors, among others, are interlinked [39]. It should be pointed out that some women may be more vulnerable to psychological postpartum events because of their atypical response to the hormonal changes that occur during pregnancy and birth [40]. Moreover, the reproductive hormones can alter the neurobiological patterns that significantly affect the mother-child relationship [41]. In fact, the HPA axis comprises cortisol, adrenocorticotropic hormone and corticotropin-releasing hormone, whose levels are altered in response to both pregnancy and stress. It is suspected that high levels of cortisol resulting from stress or pregnancy affect the mood of pregnant women [42]. This information is consistent with the findings of this study, in which the variables of "separation or divorce" and "clinical diagnosis of ZIKV infection during pregnancy," which are considered stressors, were positively correlated with severe symptoms of PPD (Table 5). In this context, other investigations have suggested that stressful events [43-47] have serious long-term effects on mother and baby [48], and that, when experienced in the perinatal period, all such events may increase the possibility of triggering PPD symptoms [49]. It is worth mentioning that the above findings were confirmed in a cohort study, which analyzed the impact of disasters on the mental health of exposed individuals and found that the number of stressful events in life are predictors of this disorder [45].

On the other hand, it is still difficult for mothers to separate the effect of a perceived threat from the direct action of the virus in triggering PPD [50-52]. In this context, ZIKV infection emerges as a new factor, which, despite its low mortality rate among mothers, has led to severe clinical conditions that can impair reproductive organs and the central nervous system (CNS) of the fetus [53]. The first reports of newborns with ZIK virusrelated malformations occurred in October 2015, after several reports of increased microcephaly in northeastern Brazil, which had spread to 27 states in the country by May 2016 [54]. In view of these events, a "Public 
Health Emergency" [55] and a "Public Health Emergency of International Concern" [56] were declared.

In this context, this study found that a clinical diagnosis of ZIKV infection during pregnancy was one of the factors responsible for the emergence of severe symptoms of IPPD detected in puerperal women $(\mathrm{OR}=19.82$; $\mathrm{CI}=5.35-73.39$ ). This finding may have been due to the confirmation of the vertical transmission of ZIKV to the fetus and its association with microcephaly [53]. Thus, it is a well known fact that, during pregnancy, the participants of this survey received alarming information about the potential problems their babies might face due to their exposure to Zika virus.

However, the greatest aggravating factor in this situation was that the interviewees clinically diagnosed in the early months of pregnancy received serological confirmation of the infection only during puerperium; in other words, they spent a large part of their pregnancy fearing that their baby might have microcephaly. In fact, the strong possibility that these pregnant women might fall ill should be seen as a public health problem, given the correlation between depression and suicide, maternal infanticide [57], early weaning [58], severe anxiety [59], late access to health services, a low number of prenatal consultations, and the fact that recommended physical examinations are often neglected [60]. Moreover, it weakens the mother-baby bond significantly [61]. Lastly, in newborns, ZIKV infection is associated with death, reduced head circumference (microcephaly) and low birth weight, as well as low Apgar scores, premature birth and congenital anomalies [62]. A possible explanation for severe fetal impairments is that pregnant women suffering from anxiety, depression and stress have high levels of cortisol that can pass through the placental barrier and worsen the fetal damage caused by ZIKV [63].

In addition to these factors, it should be pointed out that the use of ELISA for the laboratory diagnosis of Zika virus infection is an important diagnostic tool, although it is not widely available in Brazil. In addition, ELISA can generate false-positive results by cross reactions with other flaviviruses such as Dengue, which is widely distributed in tropical regions [64]. Moreover, the classic clinical symptoms of this infection are similar to those of Dengue fever and Chikungunya fever, making it difficult to diagnose clinically. In addition, the social commotion resulting from the fear of an outbreak may lead to the assumption, albeit inconsistent, that numerous diseases are caused by Zika virus [65]. Advances have been made in diagnosis, treatment and prevention strategies. Nevertheless, a clear understanding of the pathophysiology of this infection has yet to be achieved [66].

The findings of this study therefore indicated that exposure to the diagnosis of ZIKV infection, even if only clinical, had profound and possibly lasting effects on the mental health of these puerperal women, confirming its association with symptoms of PPD and exacerbating their feelings of anxiety and stress.

In view of this situation of total vulnerability, the public health authorities could implement a few interventions, such as the implementation of psychoeducational support groups aimed at coping with prenatal stress [67], including delivery [68]. Other options would be the implementation of social support programs based on information technology, on the web [69], and also on smartphone users [70]. Another suggestion is the practice of routine home visits before and after childbirth [49]. Lastly, the use of tools to screen depression during the pregnancy-puerperal cycle is recommended, as well as referral of the most critical patients to psychologists and psychiatrists.

\section{Limitations}

Some limitations of this study are the adoption of a high cut-off point (EPDS $\geq 13$ ) to avoid conflicting diagnosis, which reduced the size of the group of exposed women $(n=36)$, and the impossibility of generalizing the results to the private health sector. Although these methodological limitations did not jeopardize the relevance of this survey, additional studies are suggested.

This study addressed a unique theme and presented multiple strengths, such as the adoption of an analytical epidemiological study design, the inclusion of a large number of independent variables to evaluate possible associations, the use of an internationally recognized instrument validated in Brazil (EPDS), and a pilot study. Moreover, since this survey was conducted at the height of a pandemic, with strong emotional implications for the mother, the group selection bias and recall bias foreseen in case-control studies were minimized. Lastly, it should be noted that the sample size was calculated and was found to be representative. Although the findings of this study cannot be generalized to the private health sector, its methodological limitations do not diminish its relevance.

\section{Conclusions}

This study is contextually distant from most others in that it provides preliminary information that expands the understanding of the complex interaction between diagnosed ZIKV infection and severe symptoms of IPPD. These findings point to the need for routine screening of these symptoms, particularly in individuals with a history of marital separation in the preceding year and a diagnosis of ZIKV infection during pregnancy. In addition, it is important to plan and implement integrated preventive measures aimed at pre- and postpartum mental health. 


\section{Clinical relevance of this study}

This article identifies several needs of the victims of postpartum depression. In particular, it offers groundbreaking information about the serious association between clinically diagnosed ZIKV infection during pregnancy and the onset of symptoms of IPPD. In this context, it makes an important contribution to the diagnosis, because it broadens the perception of multidisciplinary teams to maternal suffering, thereby facilitating treatment strategies in a new area that is still poorly understood.

\begin{abstract}
Abbreviations
AAS: Abuse Assessment Screen; ABEP: Brazilian Market Research Association; CDC: Centers for Disease Control and Prevention; CEP: Research Ethics Committee; Cl: Confidence interval; CNS: Central nervous system; ELISA: Enzyme-Linked Immunosorbent Assay; EPDS: Edinburgh Postnatal Depression Scale; HPA: Hypothalamic Pituitary Adrenal axis; HPG: Hypothalamic Pituitary Gonadal axis; IPPD: Immediate Postpartum Period depression; MS: Brazilian Ministry of Health; MT: (state of) Mato Grosso; OR: Odds ratio; PPD: Postpartum depression; SD: Standard deviation; SPSS: Statistical Package for Social Sciences; UFG: Federal University of Goiás; UFMT: Federal University of Mato Grosso; USA: United States of America; VIF: Variance Inflation Factor; WHO: World Health Organization; ZIKV: Zika virus
\end{abstract}

\section{Acknowledgements}

The authors wish to acknowledge the patients who participated in this study.

\section{Authors' contributions}

EVM; ORT: also contributed to the concept and design of the study, the analysis and interpretation of data, preparation of the manuscript, and to a critical review of the manuscript. MMA; FLD; BNG; KAM; TCD; TWT; and ALC: contributed to the study design, data analysis and interpretation, and a critical review of the manuscript. All the authors read and approved the final manuscript.

\section{Funding}

This research was financially supported by the Brazilian research funding agency CAPES (Federal Agency for the Support and Improvement of Higher Education). The agency played no role in the design of this study, in the collection, analysis and interpretation of data, or in the writing of this manuscript.

\section{Availability of data and materials}

The datasets used and/or analyzed in this study are available from the corresponding author upon reasonable request.

\section{Ethics approval and consent to participate}

This research was approved by the Research Ethics Committee of UFMT under Protocol CEP/UFMT/2015 No. 975.413, in line with Resolution No. 466/12 of the National Health Council of the Brazilian Ministry of Health. All the participants gave their written informed consent willingly prior to participating in this study, and were assessed as having the functional mental capacity to do so. Moreover, no data that could identify any individual will be published.

\section{Consent for publication}

Not applicable. No data that could identify any individual will be published.

\section{Competing interests}

The authors declare that they have no competing interests.

\section{Author details}

${ }^{1}$ School of Medicine, Federal University of Goiás- UFG, Av. Primeira Avenida, s/n, Setor Leste Universitário, Goiânia, GO 74605-020, Brazil. ${ }^{2}$ Institute of Biological Sciences and Health, Federal University of Mato Grosso, UFMT, BR 070, Km 05, Barra do Garças, MT 78600-000, Brazil. ${ }^{3}$ Institute of Biological Sciences and Health, Pharmacy Course, Federal University of Mato Grosso, UFMT, BR 070, Km 05, Barra do Garças, MT 78600-000, Brazil. ${ }^{4}$ Department of Pediatrics and Child Care, School of Medicine, Federal University of Goiás, UFG, Av. Primeira Avenida, s/n, Setor Leste Universitário, Goiânia, GO
74605-020, Brazil. 5Avenida Getúlio Vargas, 663, Aragarças, GO 76240-000, Brazil.

Received: 8 December 2017 Accepted: 23 May 2019

Published online: 26 June 2019

\section{References}

1. World Health Organization, Depression: A Global Crisis. World Mental Health Day, October 10 2012, World Federation for Mental Health, Occoquan, Va, USA, 2012.

2. Scottish Intercollegiate Guidelines Network. Management of postnatal depression and puerperal psychosis. In: A national clinical guideline, guideline number 60. Edinburgh: SIGN Executive; 2002.

3. WHO World Health Organization Maternal mental health and child health and development in low and middle income countries: report of the meeting held in Geneva, Switzerland, 2008. http://www.who.int/mental_health/prevention/ suicide/mmh_jan08_meeting_report.pdf. Accessed 12 July 2017.

4. Filha MMT, Ayers S, Gama SGN, Carmo Leal M. Factors associated with postpartum depressive symptomatology in Brazil: the birth in Brazil national research study, 2011/2012. J Affect Disord. 2016;194:159-67.

5. WHO World Health Organization. Maternal mental health. [Internet] Available from: http://www.who.int/mental_health/maternal-child/maternal_ mental_health/en/. [Accessed 14 July 2017.]

6. Kessler RC, Sampson NA, Berglund P, Gruber MJ, Al-Hamzawi A, Andrade $L$, et al. Anxious and non-anxious major depressive disorder in the World Health Organization world mental health surveys. Epidemiol Psychiatr Sci. 2015;24(3):210-26.

7. O'Hara MW, Wisner KL. Perinatal mental illness: definition, description and aetiology. Best Pract Res Clin Obstet Gynaecol. 2014;28:3-12. https://doi.org/ 10.1016/J.Bpobgyn.2013.09.002.

8. Alfayumi Zeadna S, Kaufman Shriqui V, Zeadna A, Lauden A, ShohamVardi I. The association between sociodemographic characteristics and postpartum depression symptoms among arabbedouin women in southern Israel. Depress Anxiety. 2015;32(2):120-8.

9. Rodríguez MA, Valentine J, Ahmed SR, Eisenman DP, Sumner LA, Heilemann MV, et al. Intimate partner violence and maternal depression during the perinatal period: a longitudinal investigation of Latinas. Violence Against Women. 2010;16(5):543-59. https://doi.org/10.1177/ 1077801210366959.

10. CDC Centers for Disease Control and Prevention. [Internet] [Accessed 14 July 2017.] Available from: Zika Transmission. https://www.cdc.gov/zika/ prevention/transmission-methods.html.

11. MS Ministério da Saúde. Secretaria de Vigilância em Saúde - Boletim Epidemiológico. 2017;48(17). [Internet] [Accessed 15 July 2017]. Available from: http://portalarquivos.saude.gov.br/images/pdf/2017/junho/01/BE-2017-015Monitoramento-integrado-de-alteracoes-no-crescimento-e-desenvolvimento.pdf.

12. Krueger PM, Saint Onge JM, Chang WW. Race/ethnic differences in adult mortality: the role of perceived stress and health behaviors. Soc Sci Med. 2011;73(9):1312-22.

13. Slopen N, David R, Williams DR, Fitzmaurice GM, Gilman ES. Sex, stressful life events, and adult onset depression and alcohol dependence: are men and women equally vulnerable? Soc Sci Med. 2011;73(4):615-22.

14. Seib C, Whiteside E, Lee K, Humphreys J, HanhDao TMNT, Chopin L, et al. Stress, lifestyle, and quality of life in midlife and older Australian women: results from the stress and the health of women study. Womens Health Issues. 2014;24(1):e43-52.

15. Dean AG, Sullivan KM, Soe MM. Open Epi: open source epidemiologic statistics for public health, 2013. [Internet] [Accessed 16 July 2017.] Available from: https://www.openepi.com/Menu/OE_Menu.htm.

16. Araújo TVB, Rodrigues LC, Alencar Ximenes RA, Barros Miranda-Filho D, Montarroyos UR, Melo APL, et al. Association between Zika virus infection and microcephaly in Brazil, January to May, 2016: preliminary report of a case-control study. Lancet Infect Dis. 2016;16(12):1356-63.

17. Fleiss JL. Statistical methods for rates and proportions (2nd ed.). New York: Wiley; 1981.

18. Cox JL, Holden JM, Sagovsky R. Detection of postnatal depression. Development of the 10-item Edinburgh postnatal depression scale. $\mathrm{Br}$ J Psychiatry. 1987;150:782-6.

19. Santos IS, Matijasevich A, Tavares BF, Barros AJD, Botelho IP, Lapolli C, et al. Validation of the Edinburgh postnatal depression scale (EPDS) in a sample 
of mothers from the 2004 Pelotas birth cohort study. Cad Saude Publica. 2007:23(11):2577-88.

20. McFarlane J, Parker B, Soeken K, Bullock L. Assessing for abuse during pregnancy: severity and frequency of injuries and associated entry into prenatal care. JAMA. 1992;267:3176-8.

21. Reichenheim $M E$, Moraes $C L$, Hasselmann $M H$. Equivalência semântica da versão em português do instrumento Abuse Assessment Screen para rastrear a violência contra a mulher grávida. Rev Saude Publica. 2000;34(6):610-6.

22. Norton LB, Peipert JF, Zierler S, Lima B, Hume L. Battering in pregnancy: an assessment of two screening methods. Obstet Gynecol. 1995;85:321-5.

23. McFarlane J, Parker B, Soeken K. Abuse during pregnancy: association with maternal health and infant birth weight. Nurs Res. 1996;45:37-42.

24. ABEP Associação Brasileira de Empresas de Pesquisa. Critério de classificação BRASIL. [Internet] [Accessed 3 June 2017.] Available from: http://www.abep. org/codigos-e-guias-da-abep.

25. Urbina S. Fundamentos da testagem psicológica. Porto Alegre: Artmed; 2007. p. 121-212.

26. Nunnally JC. Psychometric theory, vol. 226. 2nd ed. New York: McGraw-Hill; 1967.

27. Browner WS. Publishing and presenting clinical research. Philadelphia: Lippincott Williams \& Wilkins; (3rd ed.). 2012.

28. Miloca SA, Conejo PD. Multicolinearidade em modelos de regressão. Semana acadêmica da matemática, vol. 22; 2013.

29. Gujarati DN, Porter DC. Econometria Básica-5. Amgh Editora; 2011.

30. Gomes LA, Torquato VS, Feitoza AR, Souza AR, Silva MAM, Pontes RJS Identificação dos fatores de risco para depressão pós-parto: importância do diagnóstico precoce. Revista da Rede de Enfermagem do Nordeste, Fortaleza. 2010;11:117-123. Número especial.

31. Ashley JM, Harper BD, Arms-Chavez CJ, LoBello SG. Estimated prevalence of antenatal depression in the US population. Arch Womens Ment Health. 2016;19(2):395-400.

32. Couto TC, Cardoso MN, Brancaglion MM, Faria GC, Garcia FD, Nicolato R, Corrêa $\mathrm{H}$. Antenatal depression: prevalence and risk factor patterns across the gestational period. J Affect Disord. 2016;192:70-5.

33. Moraes EV, Campos RN, Avelino MM. Depressive symptoms in pregnancy: the influence of social, psychological and obstetric aspects. Rev Bras Ginecol Obstet. 2016;38(6):293-300. https://doi.org/10.1055/s-0036-1585072 [Internet] [Cited 7 May 2019]. Available from: http://www.scielo.br/scielo. php?script=sci_arttext\&pid=S0100-72032016000600293.

34. Abdollahi F, Sazlina SG, Zain AM, Zarghami M, Asghari Jafarabadi M, Lye MS Postpartum depression and psycho-socio-demographic predictors. Asia Pac Psychiatry. 2014;6:425-34.

35. Ward TS, Kanu FA, Robb SW. Prevalence of stressful life events during pregnancy and its association with postpartum depressive symptoms. Arch Womens Ment Health. 2017;20(1):161-71.

36. Paulson JF, Bazemore SD. Prenatal and postpartum depression in fathers and its association with maternal depression: a meta-analysis. JAMA. 2010;303:1961-9.

37. Roomruangwong C, Anderson G, Berk M, Stoyanov D, Carvalho AF, Maes M. A neuro-immune, neuro oxidative and neuro-nitrosative model of prenatal and postpartum depression. Prog Neuro-Psychopharmacol Biol Psychiatry. 2017;81:262-74.

38. Stein A, Pearson RM, Goodman SH, Rapa E, Rahman A, McCallum M, Pariante CM. Effects of perinatal mental disorders on the fetus and child. Lancet. 2014;384(9956):1800-19.

39. Byrne EM, Carrillo-Roa T, Penninx BW, Sallis HM, Viktorin A, Chapman B, Sullivan PF. Applying polygenic risk scores to postpartum depression. Arch Womens Ment Health. 2014;17:519-28.

40. Bloch M, Schmidt PJ, Danaceau M, Murphy J, Nieman L, Rubinow DR. Effects of gonadal steroids in women with a history of postpartum depression. Am J Psychiatry. 2000;157:924-30

41. Pawluski JL, Lonstein JS, Fleming AS. The neurobiology of postpartum anxiety and depression. Trends Neurosci. 2017;40:106-20.

42. Giesbrecht GF, Letourneau N, Campbell T, Kaplan BJ, Apron Study Team. Affective experience in ecologically relevant contexts is dynamic and not progressively attenuated during pregnancy. Arch Womens Ment Health. 2012;15(6):481-5.

43. O'Hara MW, McCabe JE. Postpartum depression: current status and future directions. Annu Rev Clin Psychol. 2013;9:379-407.
44. Rogers $\mathrm{CE}$, Kidokoro $\mathrm{H}$, Wallendorf $\mathrm{M}$, Inder TE. Identifying mothers of very preterm infants at-risk for postpartum depression and anxiety before discharge. J Perinatol. 2013;33:171-6.

45. Demirchyan A, Petrosyan D, Armenian HK. Rate and predictors of postpartum depression in a 22-year follow-up of a cohort of earthquake survivors in Armenia. Arch Womens Ment Health. 2014;17(3):229-37.

46. Biaggi A, Conroy S, Pawlby S, Pariante CM. Identifying the women at risk of antenatal anxiety and depression: a systematic review. J Affect Disord. 2016;191:62-77.

47. Truijens SE, Spek V, Van Son MJ, Oei SG, Pop VJ. Different patterns of depressive symptoms during pregnancy. Archives of women's mental health. 2017;20(4):539-46.

48. Glover V. Prenatal stress and its effects on the fetus and the child: possible underlying biological mechanisms. In: Perinatal programming of neurodevelopment. New York: Springer; 2015. p. 269-83.

49. Lederberg-Stone S, Diop H, Declercq E, Cabral HJ, Wise LA. Eventos estressantes durante a gravidez e sintomas depressivos pós-parto. J Women's Health (Larchmt). 2015;24(5):384-93.

50. Centers for Disease Control and Prevention. Zika virus: symptoms, diagnosis, and treatment. 2016. Available from: https://www.cdc.gov/zika/symptoms/ index.html (Accessed 20 Aug 2017).

51. McCabe ERB. (2016). Zika virus infection: Evaluation of pregnant wom en and infants. Retrieved from http://www.uptodate.com/contents/zika-virusinfection-evaluation-of-pregnant-women-and-infants? source=see_link.

52. De Carvalho NS, De Carvalho BF, Fugaça CA, Dóris B, Biscaia ES. Zika virus infection during pregnancy and microcephaly occurrence: a review of literature and Brazilian data. The Brazilian Journal of Infectious Diseases. 2016;20(3):282-89

53. Oliveira MAS, Malinger G, Ximenes R, Szejnfeld PO, Alves SS, Bispo FAM. Zika virus intrauterine infection causes fetal brain abnormality and microcephaly: tip of the iceberg? Ultrasound Obstet Gynecol. 2016;47:6-7.

54. Centro de Operações de Emergências em Saúde Pública sobre Microcefalias (COES). Monitoramento dos casos de microcefalias no Brasil informe Epidemiológico 49 - Brasil 2016. Available from: http://portalarquivos2.saude. gov.br/images/pdf/2016/outubro/31/Informe_Epidemiologico_n49_SE_42_ 2016-25out2016_10h00.pdf. (Accessed 15 Dec 2016).

55. Centro de Operações de Emergências em Saúde Pública sobre Microcefalias (COES). Monitoramento dos casos de microcefalias no Brasil informe Epidemiológico N0 01 - Brasil 2015. Available from: http://portalarquivos2. saude.gov.br/images/pdf/2015/novembro/24/COES-Microcefalias---InformeEpidemiol--gico---SE-46---24nov2015.pdf. (Accessed 01 Dec 2016).

56. World Health Organization. WHO director-general summarizes the outcome of the emergency committee regarding clusters of microcephaly and Guillain-Barre syndrome. 2016. Available from: http://www.who.int/ mediacentre/news/statements/2016/emergency-committee-zikamicrocephaly/en/. (Accessed 16 Dec 2016).

57. Lindahl V, Pearson J, Colpe L. Prevalence of suicidality during pregnancy and postpartum. Arch Women's Ment Health. 2005;8(2):77-87.

58. Paul I, Downs D, Schaefer E, Beiler J, Weisman C. Postpartum anxiety and maternal-infant health outcomes. Pediatrics. 2013;131:e1218-24.

59. Bernstein $\mathrm{H}$, Rush AJ, Yonkers K, Carmody TJ, Woo A, McConnell K, et al. Symptom features of postpartum depression: are they distinct? Depress Anxiety. 2008:25(1):20-6.

60. Redshaw M, Henderson J. From antenatal to postnatal depression: associated factors and mitigating influences. J Women's Health (Larchmt). 2013;22:518-25.

61. Flynn H, Davis M, Marcus S, Cunningham R, Blow F. Rates of maternal depression in pediatric emergency department and relationship to child service utilization. Gen Hosp Psychiatry. 2004;26(4):316-22.

62. Raisanen S, Lehto SM, Nielsen HS, Gissler M, Kramer MR, Heinonen S. Risk factors for and perinatal outcomes of major depression during pregnancy: a population-based analysis during 2002-2010 in Finland. BMJ Open. 2014;4:e004883.

63. Glover V. Maternal depression, anxiety and stress during pregnancy and child outcome; what needs to be done. Best Pract Res Clin Obstet Gynaecol. 2014;28:25-35.

64. Hayes EB, et al. Zika virus outside Africa. Emerg Infect Dis. 2009;15(9):1347-50

65. ECLAMC Documento final V3. From ECLAMC Estudo Colaborativo LatinoAmericano de Malformações Congênitas. Buenos Aires, Argentina, dez. 2015. Available from: http://www.eclamc.org/descargas/6. DocumentoECLAMCFinalV3.docx. (Accessed 3 Mar 2016). 
66. Moraes EV, Toledo Or, David FL, Avelino MM . Profile of the Zika Vírus epidemic in Brasil and world wide. Indian J Appl Res. 2017;7:598-600. Available from: https://www.worldwidejournals.com/indian-journal-ofapplied-research-(IJAR)/fileview.php?val=June_2017_1496325912_185.pdf. (Acessed 3 July 2017).

67. Koushede V, Brixval CS, Thygesen LC, Axelsen SF, Winkel P, Lindschou J, et al. Antenatal small-class education versus auditorium-based lectures to promote positive transitioning to parenthood-a randomised trial. PLoS One. 2017;12(5):e0176819.

68. Duncan LG, Cohn MA, Chao MT, Cook JG, Riccobono J, Bardacke N. Benefits of preparing for childbirth with mindfulness training: a randomized controlled trial with active comparison. BMC Pregnancy Childbirth. 2017;17(1):140.

69. Ashford MT, Olander EK, Ayers S. Computer-or web-based interventions for perinatal mental health: a systematic review. J Affect Disord. 2016:197:134-46.

70. Cheng HY, Huang TY, Chien LY, Cheng YF, Chen FJ. The effects of a mobile application social support program on postpartum perceived stress and depression. Hu Li ZaZhi. 2016;63(6):52.

\section{Publisher's Note}

Springer Nature remains neutral with regard to jurisdictional claims in published maps and institutional affiliations.

Ready to submit your research? Choose BMC and benefit from:

- fast, convenient online submission

- thorough peer review by experienced researchers in your field

- rapid publication on acceptance

- support for research data, including large and complex data types

- gold Open Access which fosters wider collaboration and increased citations

- maximum visibility for your research: over $100 \mathrm{M}$ website views per year

At BMC, research is always in progress.

Learn more biomedcentral.com/submissions 